\title{
SISTEM MONITORING ODP DAN PDP COVID-19 DI GUGUS TUGAS DINAS KESEHATAN KABUPATEN KEPULAUAN MERANTI BERBASIS ANDROID
}

\author{
Zulfikri' $^{1)}$, Adhamdi Tria Putra Abza ${ }^{2)}$ \\ ${ }^{1}$ Manajemen Informatika, AMIK Selat Panjang, Jalan Terpadu Dorak No. 100 Selat Panjang \\ email: zulfikrimkom@gmail.com \\ ${ }^{2}$ Manajemen Informatika, AMIK Selat Panjang, Jalan Terpadu Dorak No. 100 Selat Panjang \\ email: dham.abza@gmail.com
}

\begin{abstract}
The Covid-19 ODP and PDP monitoring system in the Meranti Islands District Health Office task force is a system that monitors and records people who are indicated to have Covid-19 disease. In the current system, when conducting the monitoring process the task force always contacts the puskesmas in the Kepulauan Meranti District by telephone or whatsapp for the data collection and reporting process, so that monitoring data management is not computerized properly. This caused frequent delays in reporting data to the RIAU Province. Problems also occur with the amount of data due to the absence of a closing data system that results in reports of ODP and PDP Covid-19 daily data numbers always being different between puskesmas and the Health Office. To support the monitoring system of ODP and PDP Covid-19, an application is needed that can assist in the monitoring process in the task force of the Kepulauan Meranti District Health Office by utilizing Android-based technology. The author uses the programming languages Java and PHP in building monitoring ODP and PDP Covid-19 in the Health Service District of Meranti Islands. The purpose of this study is to help the task force not be late in reporting the number of ODP and PDP to the RIAU Province and to avoid differences in the amount of data between the puskesmas and the Meranti Islands Health Service task force so that the results of this study will be information about the total findings and monitoring of ODP and PDP Covid-19 every day through the Android application.
\end{abstract}

Keywords: Monitoring, Android, Covid-19

\begin{abstract}
Abstrak
Sistem monitoring ODP dan PDP Covid-19 di gugus tugas Dinas Kesehatan Kabupaten Kepulauan Meranti merupakan Sistem yang memantau dan mendata masyarakat yang terindikasi terkena penyakit Covid-19. Pada sistem yang sedang berjalan, saat melakukan proses monitoring pihak gugus tugas selalu menghubungi puskesmas-puskesmas di Kabupaten Kepulauan Meranti melalui telepon ataupun whatsapp untuk proses pendataan dan pelaporan, sehingga dalam pengelolaan data monitoring tidak terkomputerisasi dengan baik. Hal ini menyebabkan sering terjadi keterlambatan dalam pelaporan data ke Provinsi RIAU. Masalah juga terjadi terhadap jumlah data karena tidak adanya sistem closing data yang mengakibatkan laporan jumlah data harian ODP dan PDP Covid-19 selalu berbeda antara puskesmas dan Dinas Kesehatan. Untuk mendukung sistem monitoring ODP dan PDP Covid-19, maka diperlukan sebuah aplikasi yang dapat membantu dalam proses monitoring di gugus tugas Dinas Kesehatan Kabupaten Kepulauan Meranti dengan memanfaatkan teknologi berbasis Android. Penulis menggunakan bahasa pemograman Java dan PHP dalam membangun monitoring ODP dan PDP Covid-19 di Dinas Kesehatan Kabupaten Kepulauan Meranti. Tujuan dalam penelitian ini untuk membantu gugus tugas agar tidak terlambat dalam melaporkan jumlah ODP dan PDP ke Provinsi RIAU serta menghindari perbedaan jumlah data antara puskesmas dan gugus tugas Dinas Kesehatan Kabupaten Kepulauan Meranti sehingga hasil dari penelitian ini berupa informasi tentang total hasil penemuan dan pemantauan ODP dan PDP Covid-19 setiap hari melalui aplikasi Android.
\end{abstract}

Kata Kunci: Monitoring, Android, Covid-19 


\section{PENDAHULUAN}

Gugus Tugas Percepatan Penanganan Corona Virus Disease 2019 (COVID-19) adalah sebuah gugus tugas yang dibentuk pemerintah Indonesia untuk mengkoordinasikan kegiatan antarlembaga dalam upaya mencegah dan menanggulangi dampak penyakit koronavirus baru di Indonesia. Gugus tugas ini dibentuk pada 13 Maret 2020 berdasarkan Keputusan Presiden Nomor 7 Tahun 2020 tentang Gugus Tugas Percepatan Penanganan Corona Virus Disease 2019 (COVID-19) dan berada di bawah serta bertanggung jawab langsung pada presiden Indonesia. Gugus tugas ini berada dalam lingkup Badan Nasional Penanggulangan Bencana, dengan melibatkan kementerian, lembaga, dan unit pemerintahan lain seperti Kementerian Kesehatan, Kepolisian Negara Republik Indonesia, Tentara Nasional Indonesia, dan pemerintah di daerah. Gugus tugas ini dibentuk tidak hanya di tingkat nasional, tetapi juga di tingkat provinsi dan kabupaten/kota.

Berdasarkan analisis kebutuhan perangkat lunak yang penulis lakukan pada gugus tugas Dinas Kesehatan Kabupaten Kepulauan Meranti, proses monitoring ODP dan PDP Covid-19 dilakukan dengan cara menghubungi puskesmas-puskesmas menggunakan telepon atau whatsapp. Jika ditinjau dari efektifitas kinerja masih belum efektif, karena sering terjadinya keterlambatan dalam melaporkan data ke Provinsi RIAU dan jumlah data ODP dan PDP yang selalu berbeda antara puskesmas dan gugus tugas Dinas Kesehatan.

Tujuan pada penelitian ini yaitu untuk membantu gugus tugas Dinas Kesehatan Kabupaten Kepulauan Meranti dalam mendata dan mengelola data ODP dan PDP dalam bentuk sistem basis data sehingga hasil yang diperoleh adalah data ODP dan PDP yang telah tersimpan di sistem basis data dapat di jadikan sebagai media informasi jumlah penemuan dan pemantauan ODP dan PDP di setiap puskesmas yang tersebar di kecamatankecamatan. Manfaat yang diperoleh dalam penelitian ini adalah gugus tugas Dinas Kesehatan Kabupaten Kepulauan Meranti dapat memonitoring jumlah ODP dan PDP melalui media internet menggunakan smartphone berbasis Android tanpa harus menghubungi ataupun whatsapp ke masing-masing puskesmas yang tersebar di kecamatankecamatan Kabupaten Kepulauan Meranti.

\section{METODE PENELITIAN}

Metode penelitian yang digunakan oleh penulis adalah model pengembangan perangkat lunak metode air terjun (Waterfall) yang menyediakan pendekatan alur hidup perangkat lunak secara sekuential atau terurut dimulai dari analisis, desain, pengkodean, pengujian dan tahap pendukung (Muhammad \& Eni, 2017).

Terdapat beberapa tahap yang penulis lakukan dalam pengumpulan data pada metode air terjun untuk membangun sistem monitoring ODP dan PDP Covid19 di gugus tugas Dinas Kesehatan Kabupaten Kepulauan Meranti, yaitu :

1. Analisis Kebutuhan Perangkat Lunak Proses pengumpulan kebutuhan dilakukan secara intensif untuk mendapatkan spesifikasi kebutuhan perangkat lunak yang dibutuhkan oleh pengguna aplikasi. Metode yang digunakan dalam analisis kebutuhan perangkat lunak yaitu dengan wawancara secara kepada tim gugus tugas Covid-19 Dinas Kesehatan Kabupaten Kepulauan Meranti.

2. Desain

Desain perangkat lunak merupakan proses yang dilakukan secara langkah demi langkah pada desain pembuatan aplikasi termasuk struktur data, 
arsitektur perangkat lunak, representasi antarmuka dan prosedur pengkodean. Tahap ini mentranslasi kebutuhan dari analisis kebutuhan perangkat lunak ke representasi desain agar dapat di implementasikan menjadi program pada tahap selanjutnya. Metode yang digunakan dalam melakukan desain aplikasi yaitu dengan menggunakan Konteks Diagram, Data Flow Diagram dan Entity Relationship Diagram.

3. Pembuatan Kode Program

Desain harus di translasikan ke dalam bentuk perangkat lunak. Hasil dari tahap ini adalah aplikasi yang sesuai desain yang dibuat pada tahap desain. Pada tahap ini, proses pembuatan kode program dengan menggunakan Bahasa Pemrograman JAVA pada sisi client, PHP pada sisi server dan sistem basis data menggunakan MySQL

4. Pengujian

Pengujian perangkat lunak dilakukan dari segi logika dan fungsi aplikasi serta memastikan bahwa semua bagian telah di uji. Hal ini dilakukan agar aplikasi tidak mengalami kesalahan (error) dan memastikan aplikasi memiliki keluaran sesuai yang di inginkan. Pada tahap pengujian, metode yang digunakan adalah metode Black Box yaitu dengan menguji hasil dari tampilan aplikasi.

5. Pendukung atau Pemeliharaan

Tahap pendukung atau pemeliharaan dilakukan untuk perubahan terhadap perangkat lunak yang telah digunakan oleh pengguna. Perubahan bisa saja terjadi karena adanya kesalahan yang muncul dan tidak terdeteksi pada saat pengujian aplikasi. Tahap ini juga mendukung proses pengembangan perangkat lunak dari analisa kebutuhan perangkat lunak namun tidak untuk membuat perangkat lunak yang baru. Pada tahap ini, metode pemeliharaan yang dilakukan adalah dengan metode Korektif yaitu dengan mengoreksi kesalahan-kesalahan yang ditemukan pada saat sistem yang berjalan.

\section{HASIL DAN PEMBAHASAN}

Untuk mendapatkan hasil yang sesuai dengan kebutuhan pengguna, penulis melakukan tahap perancangan aplikasi dengan menggunakan Konteks Diagram, Data Flow Diagram dan Entity Relationship Diagram sebagai berikut :

1. Konteks Diagram

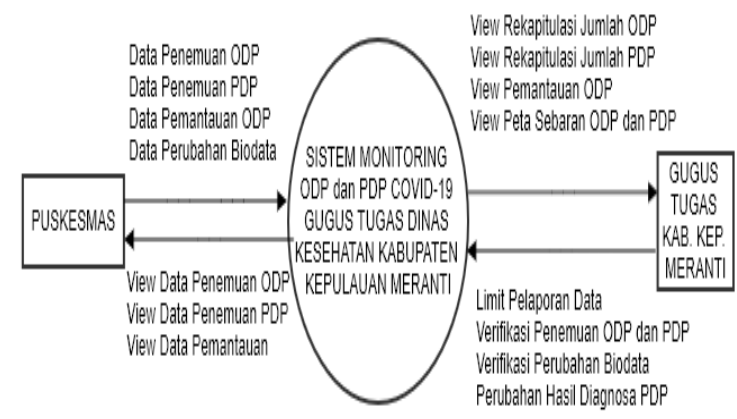

\section{Gambar 1 : Konteks Diagram Sumber : Adhamdi Tria Putra Abza}

Penjelasan dari Gambar 1 adalah, Puskesmas dapat melakukan proses input, update, delete dan view pada data ODP dan PDP serta melakukan perubahan biodata terhadap ODP dan PDP. Setelah Puskesmas melakukan proses input data, Gugus Tugas Dinas Kesehatan Kabupaten Kepulauan Meranti dapat melihat data ODP dan PDP serta peta sebaran ODP dan PDP. Gugus Tugas juga mengatur limit waktu pelaporan data setiap harinya agar tidak terjadi perbedaan data antara Puskesmas dan Dinas Kesehatan Kabupaten Kepulauan Meranti. Gugus Tugas juga melakukan verifikasi penemuan ODP, verifikasi perubahan biodata dan verifikasi perubahan hasil 
diagnosa PDP agar tidak terjadi kesalahan data.

2. Data Flow Diagram Level 0

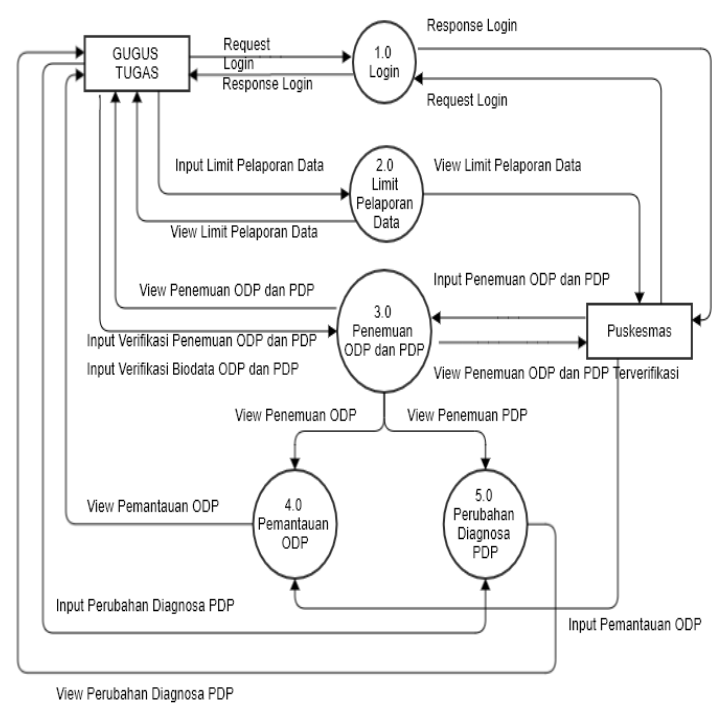

\section{Gambar 2 : Data Flow Diagram Level 0 Sumber : Adhamdi Tria Putra Abza}

Penjelasan dari Gambar 2 adalah, proses pertama yang dilakukan oleh Gugus Tugas yaitu dengan melakukan request login dan apabila response login berhasil maka Gugus Tugas melakukan proses kedua yaitu memasukkan data limit pelaporan data sehingga puskesmas nantinya hanya bias melakukan proses input data sesuai waktu limit yang telah ditentukan oleh Gugus Tugas. Selanjutnya Puskesmas melakukan request login dan apabila response login berhasil maka Puskesmas melakukan proses ketiga yaitu memasukkan data penemuan atau perubahan biodata ODP dan PDP, lalu Gugus Tugas akan memasukkan verifikasi hasil dari penemuan ataupun perubahan biodata. Dalam proses keempat, Puskesmas memasukkan hasil pemantauan ODP yang dapat dilihat hasilnya oleh Gugus Tugas. Pada proses kelima, Gugus Tugas memasukkan perubahan hasil diagnosa dari PDP.
3. Entity Relationship Diagram

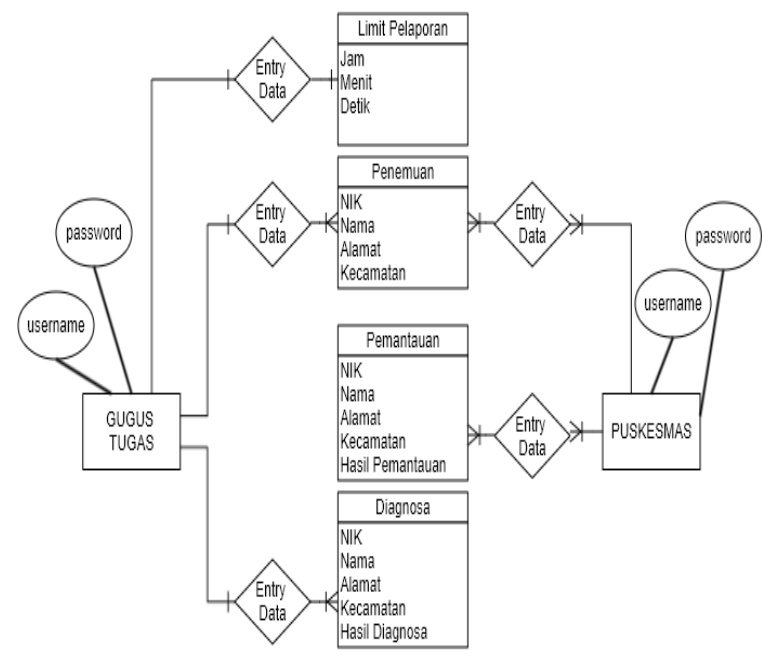

\section{Gambar 3 : Entity Relationship Diagram}

\section{Sumber : Adhamdi Tria Putra Abza}

Penjelasan dari Gambar 3 adalah, Seorang Gugus Tugas dapat melakukan satu entry data terhadap limit waktu pelaporan dan dapat melakukan banyak entry data terhadap penemuan dan diagnosa. Selanjutnya banyak puskesmas data melakukan banyak entry data terhadap penemuan dan pemantauan.

Hasil yang didapat dari penelitian ini adalah suatu sistem monitoring ODP dan PDP Covid-19 di gugus tugas Dinas Kesehatan Kabupaten Kepulauan Meranti berbasis Android dengan memanfaatkan media internet dan smartphone dalam melakukan pengolahan data dan informasi sehingga gugus tugas dan puskesmas dapat mengakses data dan informasi secara online. Data yang ditampilkan dalam sistem ini berupa jumlah data penemuan ODP, jumlah data pemantauan ODP, jumlah data PDP dan peta sebaran ODP dan PDP. Berikut merupakan bentuk 
tampilan dari sistem monitoring ODP dan PDP Covid-19 di gugus tugas Dinas Kesehatan Kabupaten Kepulauan Meranti berbasis Android.

1. Hasil perancangan data jumlah penemuan dan pemantauan ODP dan PDP

Hasil dari perancangan jumlah penemuan dan pemantauan ODP dan PDP berupa rekapitulasi ODP bergejala belum dipantau, ODP tanpa gejala belum dipantau, ODP dalam pemantauan, ODP selesai pemantauan, ODP total, ODP bergejala, ODP tanpa gejala, PDP masih dirawat, PDP Sehat, PDP meninggal dan PDP total. Berikut adalah tampilan hasil dari perancangan data jumlah penemuan dan pemantauan ODP dan PDP pada Gambar 4 dibawah ini.

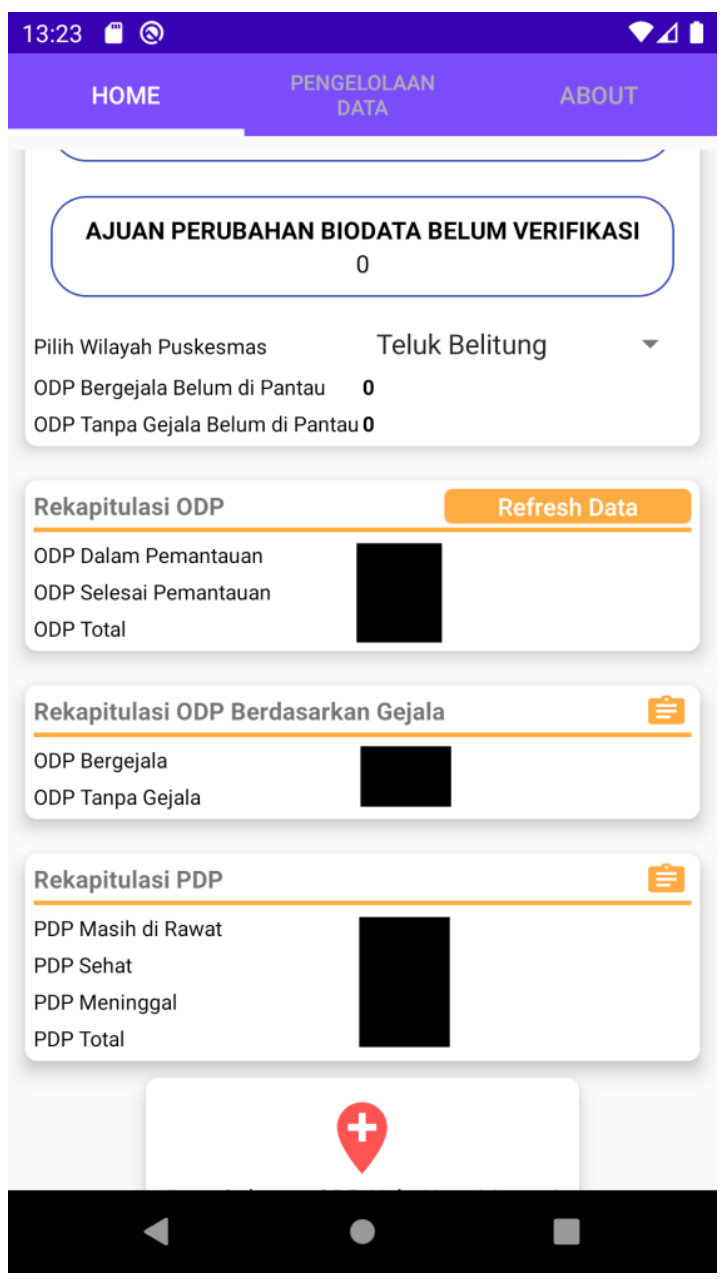

\section{Gambar 4 : Jumlah Penemuan dan Pemantauan ODP dan PDP Sumber : Adhamdi Tria Putra Abza}

2. Peta sebaran ODP dan PDP Hasil dari perancangan peta sebaran ODP dan PDP berupa tampilan geografis Kabupaten Kepulauan Meranti di mana terdapat marker-marker kecamatan yang terdapat ODP dan PDP. Berikut adalah tampilan hasil dari perancangan peta sebaran ODP dan PDP pada Gambar 5 dibawah ini.

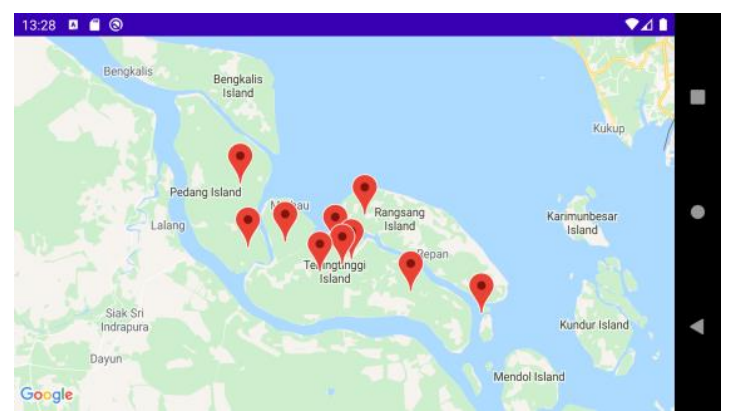

Gambar 5 : Peta Sebaran ODP dan PDP

\section{Sumber : Adhamdi Tria Putra Abza}

\section{SIMPULAN}

Kesimpulan dari penelitian ini adalah, sistem monitoring ODP dan PDP Covid19 di gugus tugas Dinas Kesehatan Kabupaten Kepulauan Meranti berbasis Android dapat menyelesaikan masalah terkait dengan pelaporan data secara tepat waktu karena puskesmas di berikan limit waktu setiap hari dalam memasukkan data penemuan dan pemantauan ODP dan PDP. Limit waktu setiap haru juga menyebabkan data yang ada di puskesmas dan data yang ada di gugus tugas dinas kesehatan kabupaten kepulauan meranti selalu sama setiap harinya Karen puskesmas tidak akan bias lagi memasukkan pemantauan dan penemuan ODP dan PDP apabila limit waktu harian 
telah habis. Tentunya dalam sistem monitoring ODP dan PDP Covid-19 di gugus tugas Dinas Kesehatan Kabupaten Kepulauan Meranti berbasis Android ini terdapat beberapa kekurangan seperti tidak mengelola data masyarakat yang terindikasi positif Covid-19. Untuk pengembangan berikutnya, sistem ini bisa melakukan pendataan terhadap masyarakat yang terindikasi positif Covid-19 di Kabupaten Kepulauan Meranti.

\section{UCAPAN TERIMAKASIH}

Penelitian ini dapat dilaksanakan dengan bantuan banyak pihak, untuk itu diucapkan terima kasih kepada : Tim Gugus Tugas Kabupaten Kepulauan Meranti dan Kepala Dinas Kesehatan Kabupaten Kepulauan Meranti

\section{DAFTAR PUSTAKA}

Halim Maulana, 2016. Analisis dan Perancangan Sistem Replikasi Database MySQL dengan Menggunakan VMWare pada Sistem Operasi Open Source. Volume 1, Nomor 1.

Harison \& Ahmad Syarif, 2016. Sistem Informasi Geografis Sarana pada Kabupaten Pasaman Barat. Volume 4, Nomor 2.

Harni Kusniyati \& Nicky Saputra Pangondingan Sitanggang, 2016. Aplikasi Edukasi Budaya Toba Samosir Berbasis Android. Volume 9, Nomor 1.

Nelly Monica, Sumitro Sarkum \& Iwan Purnama, 2018. Aplikasi Data Mahasiswa Berbasis Android : Studi Pada Sekolah Tinggi Ilmu Ekonomi Labuhanbatu. Volume 3, Nomor 1.
St. Hajrah Mansyur \& Ichroman Raditya Duwila, 2017. Perancangan Aplikasi Monitoring PC Berbasis Desktop Pada Program Studi Teknik Informatika Fakultas Ilmu Komputer UMI. Volume 9, Nomor 2. 